Shruti Das*

\title{
COUNTER-NARRATING: RE-CONSTRUCTING "SITA" IN AMISH'S SITA: WARRIOR OF MITHILA
}

\begin{abstract}
Counter-narration re-casts existing narratives and foregrounds the marginalised by giving them agency and performativity. They are narratives that challenge and provide resistance against dominant and hegemonic grand narratives which have been instrumental in formulating a social ideology over a long period of time making them normative. The Ramayana, an ancient epic is a multi-layered story of Prince Rama and Princess Sita and their role in the politics of power, state and patriarchy. It is a grand or master narrative that presupposes the passivity of the female as normative. It portrays Sita, King Rama's wife, as someone who experiences marginalization and oppression and is a victim of the dominant narrative of patriarchy. This paper will use the theory of counternarrative and analyse Amish Tripathi's novel Sita: Warrior of Mithila (2017) in order to show how he has recast Sita deconstructing the myth of passivity. Here, Sita resists prescriptive norms of the dominant narrative, wherein she has been projected as the silent receptor and problematizes the patriarchal ideology propagated through the master narrative. This paper will show how counter storytelling or counter narrating by Amish Tripathi has challenged and defied the narrative silence and hegemony in The Ramayana, while making the female powerful and capable in education, warfare and state governance.
\end{abstract}

Keywords: master-narrative; The Ramayana; Manusmriti; counter-narrating; Sita; reclaimed myth.

The purpose of this paper is to reflect and discuss how the twenty-first century writer, Amish Tripathi in his novel Sita: Warrior of Mithila (2017)has appropriated and reconstructed and problematized the passive female depicted in the dominant Hindu patriarchal master-narrative The Ramayana using a counter-narrative perspective. The Ramayana an ancient epic is a multi-layered story of Prince Rama and Princess Sita and their role in the politics of power,

* Berhampur University; India. 
state and patriarchy. The Ramayana narrates various important activities of the Princes of Ayodhya, a kingdom in Northern India, delineating their remarkable valour and principles. The story is a depiction of a patriarchal society where the patriarchal hierarchy of lineage is strictly observed. Prince Rama, the son of King Dasaratha is idolized as the ideal man, brave, just, reverential and extremely obedient to his father. He relinquishes the throne as crown prince and goes away to the Dandaka forest on exile for fourteen years as per his father's wish. Even his marriage to Sita, the Princess of Mithila is an act of masculine valour where he strings the proverbial invincible Shiva Dhanu or the great bow of Lord Shiva, the powerful member of the Hindu triumvirate and thus wins his bride. This kind of marriage, known as "swayamvara," or self-choice in taking a husband, is valorised and corroborates the Hindu patriarchal ideology that a woman is a man's property to be won, bought or given in marriage. It is believed "that a woman's 'nature' is an inevitable consequence of her reproductive roles."(Morris 1-2) Her wishes and voice are taken for granted and are of little or no consequence. The woman is passive and lacks agency revealing that gender roles are prescriptive and considered to be natural where women are more subservient and less adventurous than men.

The Ramayana as a text has moved beyond the geographical boundaries of India into many South East Asian countries like Indonesia, Malaysia, and Cambodia. The text has also travelled across different media such as in its oral and written forms. It has been rewritten from various perspectives many times and performed on stage across India and other countries of South East Asia and various aspects of the story remain iconic. Archana Pathak Bhatt in her article titled "The Sita Syndrome: Examining the Communicative Aspects of Domestic Violence from a South Asian Perspective" (2008) claims that "Sita's story is well known throughout the South Asian communities both in South Asia and in the U.S. diaspora. The story is passed down through long standing oral traditions as well more contemporary political and media outlets" (155). Basuki and Setiawan in their essay, "Reinterpreting Ramayana: The (Re)Production of the Meanings of Power in "Ramayana", an East Javanese Shadow Puppet Performance Text" (2012) discuss the re-production of Ramayana in an Indonesian puppet show where Indonesian writer Ki Sinarto's audio recorded text Ramayana makes a subversive interpretation of Sita. They note that Sita, in the Ramayana could be the incarnation of the goddess of prosperity, Vedavati. Sinarto's narrative is a variant of the original Ramayana of Valmiki. As an example, we see that Sita is 
dumped by Vibhishana as an infant for fear of Ravana's intention of marrying her own daughter to get - prosperity revelation. Ravana keeps on looking for his daughter, until finally he gets informed by Togog, his servant, who knows what has actually happened to his baby girl. When Ravana finally meets Sita, she has become the wife of Rama. Ravana discovers Sita when she is left alone in the jungle by Rama, who is at that moment disappointed for not being crowned king of Ayodhya. Ravana finally takes Sita to Lanka. To get his wife back, Rama attacks Lanka, not knowing that he is actually attacking his father-in-law. After the death of several knights including Kumbhakarna, the brother of Ravana, Ravana and Rama finally meets face to face. In this meeting Ravana blames Rama for the chaos since, as the incarnation of Vishnu, he cannot see the truth. The story ends when Ravana leaves Rama alone to ponder upon Ravana's words. (78)

Sinarto's story is a rewriting of the original Ramayana. In his version of the story projects the evil Ravana of the original story as the wronged father of Sita. Similarly, Chitra Banerjee Divakaruni's novel The Forest of Enchantments (2019) rewrites the original epic. In Valmiki's Ramayana, Sita experiences marginalization and oppression and is a victim of the dominant narrative of patriarchy. Divakaruni's Sita questions the taken-for-granted assumptions and prescriptive norms of the dominant narrative wherein she has been projected as the silent receptor. Divakaruni's narrative deviates from the original in that it refuses to accept that Sita miraculously arose from the ground, which deifies Sita and mystifies a birth story thus denying sense-making and sense-giving. In Divakaruni's story King Janaka himself narrates it, as part of family lore, to his wife and daughters. The scene and situation of discovery remain the same. Janaka had been ploughing a piece of land for a sacred purpose when he chances upon the abandoned baby Sita. Sita re-narrates the story told by her father intercepting it with comments of her own.

A baby lay in his path, naked and newborn, glistening in the young sun as though it was a mirage. He was amazed that I didn't cry, regarding him instead with unblinking eyes. I had kicked off the cloth that swaddled me, a gold fabric finer than anything our Mithila weavers could produce....Sceptics wondered which cunning person had placed me there, at just the right moment, to be discovered by Janaka. It must have been someone who knew my unworldly father well...Other kings would have 
University of Bucharest Review $\propto$ Vol. XI/2021, no. 2 (new series)

Re-writing, Re-imagining the Past (IV)

had the child removed without considering her fate. At best they would have ordered for her to be brought up in a servant's home. But my saintly father picked me up and held me to his chest. (Divakaruni 6)

The child is brought up by Janaka's childless wife Queen Sunaina, who trains her not only in womanly things but also in martial arts. She engages women from the hills to come and teach Sita the art of defence. They teach her to use her body such that it "itself could become a weapon". Sita "learned to move like a panther on the hunt, to run and leap and climb in silence, to fall the right way without injury, to accept pain when it came" (10). Divakaruni's narration serves to deconstruct the stereotype of the ideal Sita, pliant, subservient and homely given in the original Ramayana. Devakaruni, has challenged the narrative silence accorded to the female character in the original text. Although she has given Sita agency and made her a participant in her relationship with Rama and has made the story rational and somewhat romantic, she has kept Sita secluded in the world of women, thus the story reads like a close cousin of the original text. Simply rewriting a canonical text is not enough to trace and address the gender norms prescribed in India's socio-cultural code, it is simultaneously important to re-examine India's complex history and cultural past and to recreate a new narrative concerning women in India which can only be achieved through counter-narrating the cultural/canonical texts.

\section{Counter-narrative}

Matti Hyvarinen, in her review essay "Narrative Contestations" (2007) is of the opinion that "the themes of silenced, forgotten or marginalized narratives reemerge constantly" (1) and that humanities is concerned about the conventionality of the narrative and its structural patterns therein.

Following this lead, scholars sometimes wanted to show how people are always telling the same story, with only slight variation. The "narrativist" historian Hayden White understood historical narrative as being imposed on the factual plurality of events and, therefore, equalled the need to narrativize and to moralize. There is no shortage of literature proffering narrative a straightforward ideological and/or political role-be it benign or detrimental. (1-2) 
Hyvarinen further argues that the vocabulary of the counter-narrative dislodges the dominant, hegemonic narrative of the master-narrative and foregrounds narratives that resist any narrative essentialism (Hyvarinen n.pg.). Similarly, Marita Svane believes that "[i]n theorizing counter-narratives, it is important to reflect on what kind of entities counter-narratives are. Do they exist in a similar way to master-narratives or is their ontological status, their mode of being, different?" (36) She holds that the "theorization of master-narratives has been dominated by François Lyotard's conceptualization of grand narratives that have a legitimizing role, such as the narratives of Enlightenment or Marxism. Others have used the notions of dominant cultural narratives, culturally dominant narrative models or scripts, to draw attention to how certain narrative models have normative power to guide people's actions." (36) On the other hand, "[c]ounternarratives are conceptualized in relation to master-narratives, as narratives that resist and challenge them" (36). Narratives or stories can be constructive or destructive depending upon the narrator and her socio-cultural environment. Eric McDowell talks about the "'danger of narrative" - how stories can distract us from thinking critically to make harmfully distorted representations seem natural and true" (McDowell n.pg.). He analyses John Keene's argument on counter-narratives, claiming that "Keene's counter-narratives both demonstrate and enact the power of narrative. They not only use important stories to assert the dignity of misrepresented characters and invite our empathy, but they also ask us to think critically about how stories wield their power" (McDowell n.pg.).

\section{Sita reconstructed: Amish Tripathi's Sita: Warrior of Mithila}

In their essay "Introduction: What counter-narratives are: Dimensions and levels of a theory of middle range" (2021) Klarissa Lueg, Ann Bager and Marianne Lundholt are concerned about the necessity of counter-narratives. They contend that:

[b]eing observant of narratives represented in the social world, and of the power relations they are embedded in, can contribute to the gathering of insights on marginalized positions. Stories revealing these marginalized views can be called counter-narratives. Counter-narratives resist another narrative, this one often being, or being perceived as being, more powerful. Most affirmatively, counter-narratives can be interpreted as creative, innovative forces fostering beneficial societal change; forces holding 
productive potential for progress, development, as well as for ethical issues such as justice and accessible resources. Counter-narratives cannot be reduced to emancipatory, liberating or constructive stories. Instead, they can be hostile, and destabilizing: phenomena such as the loosely organized misogynist "manosphere" (4)

Power relations embedded in the Ramayana follow the codes inscribed in the Manu Smriti which prescribe the marginalization of women denying them participation in socio-political life."[O]rdinary women were kept in their domestic place by the misogynist authors of Manu Smriti, which may have been simply a normative manual but which some later Hindus regarded as their sacrosanct law code" (Ananta Raman, xiii). Amish's Sita: Warrior of Mithila reconceptualises and destabilizes the master narrative in The Ramayana challenging and resisting the patriarchal ideology embedded therein rather than being merely emancipative, liberating and constructive. In this context it will not be far-fetched to recall Serpil Oppermann's argument regarding historicity and textuality of a narrative and postmodern narratives. She talks about the New Historicist debate which holds that history can merely be a "verbal construct" and the texts, literal or historical, are testimonies of the past. She cites Jonathan Culler as saying that "history manifests itself in narrative constructs, stories designed to yield meaning through narrative ordering" (qtd. in Oppermann 14)

Daniel Taylor asserts that "[a] story is the telling of the significant actions of characters over time." (Taylor 15) He notes four aspects of story. The first is the telling aspect of the story that first marks its humanity, sending it out into the world as an act of faith. The second aspect is something to tell, something worth telling, that matters to the teller, to the listener. The third aspect is the character, what Taylor defines as "a bundle of values in action. Character is what we are at our core, our essence, that which is remembered long after a story is forgotten. Taylor's fourth aspect is the telling of significant actions of characters over time." (qtd. in Bennet 2)

The story of the original Ramayana typically adheres to Taylor's four aspects of storytelling. His "second aspect" - "something to tell, something worth telling, that matters to the teller, to the listener" and the "third aspect" - "the character", defined as "a bundle of values in action" is what the grand narrative is about. For centuries, since sage Valmiki wrote this epic, the story has mattered to the Indian teller and listener so much so, that the characters have grown in 
dimension and attained the status of social symbols of virtue and vice. The stories in this grand narrative reinforce the patriarchal ideology that the ideal story has the male at the centre and in charge of situations, while the woman is at the margins and always secondary subscribing to the patriarchal gender role of "good girl" always virtuous and submissive. Prince Rama, the central character is a bundle of patriarchal values which have been emulated by the ideal male in Indian stories over centuries and Sita has embodied another set of values that point to the subservient ideal female.

The history of the birth of Sita is mysterious and is constructed to complement patriarchal ideology that a mere human female born in ordinary circumstances cannot be the consort of the godly Prince Rama. The patriarchal binary of male domination and female subordination has been challenged oftentimes in feminist discourse in the late twentieth and twenty-first centuries. Writers use various tools to subvert patriarchal story telling. Amish Tripathi's Sita: Warrior of Mithila is a case in point. He engages in counter-storytelling, destabilizing and challenging the patriarchal ideology held dear by the Hindu society. He foregrounds the marginalised characters by giving them agency and performativity. Amish has reclaimed the myth of the passive Sita and used it, in his distinct way, as a form of resistance that problematizes the patriarchal ideology propagated through the patriarchal narrative. Within the limited scope of this paper I have chosen a few examples from Amish Tripathi's narrative and attempted to show how he his characters and storyline have resisted the master narrative replete with patriarchal ideology.

In the Ayodyakandam, Section CXVIII, Sita narrates the story of her birth to Saint Atri's wife Anasuya. She says:

Mithila's lord, the heroic Janaka, justly ruleth the earth, engaged in observing the duties of Khsatriyas. As he was ploughing a plain intended for a sacrifice, I rose from under the earth.... Tending me with my body covered with dust, Janaka, engaged in throwing handfuls of dust (to level hollow spots) was struck with amazement. Being childless, he took me upon his lap from affection, and saying- 'This is my daughter', conceived affection for me. (500)

King Janaka immediately hears an oracle saying "O King in all righteousness this daughter is yours". He therefore takes the child to his eldest 
wife for care and upbringing. Sita grows up in opulence and love as befits a princess of those times. Like all girls, she is taught the stree-dharma or the ways to be adopted by a virtuous woman in her maternal home as well as her husband's household. The simple story of Sita's birth, her life in her father's home as a delicate princess and then her normative role as a devoted wife and daughter-inlaw in her husband's home has been radically reconstructed by Amish Tripathi. Recalling Chimamanda Ngozi Adichie argument in favour of a multiplicity of stories is pertinent in this context. Eric McDowell in his review "Counternarratives: The Power of Narrative" asserts that

In her well-known TED Talk, "The Danger of a Single Story," Chimamanda Ngozi Adichie argues for the importance of a multiplicity of stories, voices, and perspectives in order to do justice to the fullest range of experience and explode reductive stereotypes of people and places. "Stories matter," she says. "Many stories matter. Stories have been used to dispossess and malign. But stories can also be used to empower and to humanize. Stories can break the dignity of a people, but stories can also repair that broken dignity."(McDowell n. pg.)

Indeed Amish Tripathi uses a range of modern day female experience, where women are required to be trained in martial arts and self defence, in his reconstruction of the Sita of the ancient epic. He adds yet another story line to depict the birth of Sita to humanize her. He uses fantasy to give the story a new perspective. He empowers the feminine and constructs an empathetic relationship between the human and the non-human. His description of the discovery of the foundling Sita is more dramatic than any before. Baby Sita is not found in a furrow while ploughing the field, but is rescued by Queen Sunaina from the forest. We read that while returning from a pilgrimage the king and the queen spot a vulture being attacked by a pack of wolves. As the brave and compassionate queen, and not the king, goes to save the vulture she finds the vulture protecting a baby by risking its own life.

Sunaina was perhaps fifty metres away when she noticed the bundle for the first time. The vulture was protecting it from the pack of wolves. It was lodged in what looked like a little furrow in the dry mud.

The bundle moved. 
'By the great Lord Parshu Ram!' exclaimed Sunaina. 'That's a baby!'

Sunaina pressed forward, rapidly goading her horse into a fierce gallop.

As she neared the pack of wolves, she heard the soft, frantic cries of a human baby, almost drowned out by the howling animals....The child, wrapped in a rich red cloth with black stripes, was crying desperately. She signalled a soldier to pick up the precious bundle as she continued to soothe the bird. (Tripathi 17)

The description that follows deconstructs the patriarchal authority of the original myth and renders it realistic and humane. Janaka and Sunaina get the royal doctor to examine the baby and "bandaged a wound on her right temple with some herbs and neem leaves" (19). The childless couple decide to keep the baby as a blessing from Devi Kanyakumari and name her Sita. At this point the present story is merged with the narrative of the original story that since the baby was found in a furrow she is called Sita. (20) The original epic does not give any space to Janaka's wife Sunaina. But Amish Tripathi's narrative sees both Sunaina and Sita as empowered females, adept in military activities and statecraft, while the King Janaka is portrayed as a passive philosophical person, who would rather the kingdom of Mithila be ruled by his wife.

Hayden White maintains that the writing of history is not strictly based on facts rather it is a "poetic process." The "historical narratives" are in fact "verbal artifacts," and the manner in which history is represented is "essentially provisional" (42). Historically, Indian women subscribed to the domination of the codes of conduct imposed on them by the Manusmriti. They were not to participate in activities reserved for men like education, martial arts, state craft or even seen in a place where there were unknown male members. Hriday $\mathrm{N}$. Patwari notes that,

5/151. Girls are supposed to be in the custody of their father when they are children, women must be under the custody of their husband when married and under the custody of her son as widows. In no circumstances is she allowed to assert herself independently.

$5 / 158$. Women have no divine right to perform any religious ritual, nor make vows or observe a fast. Her only duty is to obey and please her husband and she will for that reason alone be exalted in heaven. (The Modern Rationalist n.pg.) 
By way of counter-narration Amish Tripathi creates a new set of "verbal artefacts" more faithful to contemporary notion of the empowered female. In chapter one of the novel, he introduces Sita as a valiant woman, intelligent, powerful and adept in warfare who single handed combats the vicious militia of the enemy Raavan. Amish portrays her as a great archer, we read "There were great archers who could shoot arrows by relying on sound. But very few could throw knives at the source of a sound. Sita was one of those very few." (4) The master-narrative is resisted and destabilized as the present narrative violates the codes of Manusmriti as regards woman's education. In keeping with women rights Amish's Sita is given equal opportunity in every aspect of life. In Chapter four her parents, Janak and Sunaina, decide that Sita was "old enough to leave for gurukul; literally, the Guru's family, but in effect a residential school [that] offered lessons in the core subjects of Philosophy, Mathematics, Science, and Sanskrit. Sita would also receive education in other specialised subjects like Geography, History, Economics, and Royal Administration, among others" (42-3) (parenthesis mine). She was also to learn warfare and martial arts. Her guruor teacher, Shvetaketu praises her wisdom, pragmatism and fighting spirit (51). The patriarchal post-vedic master narrative does not give Sita the right and hence occasion to perform any religious rituals but here we find her guru, Shvetaketu and the great sage Vishwamitra engaging her in secret rituals so that she can defeat the evil and become instrumental in maintaining peace in the world.

Amish Tripathi inscribes a new history making Sunaina and Sita active in the public domain. Sita leaves her gurukul and returns to take over the reins of Mithila and help her father rule the state after the death of her mother, Sunaina. "The sixteen-year-old Sita had been administering the kingdom reasonably well. She had consolidated her rule by retaining the team that had advised Sunaina, careful to continue systems that her mother had instituted" (107). Amish's counter-narrative posits a fresh set of "verbal artefacts" by making Sita, a female, the ruler and decision maker in public domain. She does not depend upon a male to guide her, she rather proves to be an able economist and a deft politician. Her uncle, Kusadhwaja, the ruler of the neighbouring kingdom always wanted to freeze Mithila's trade and resources. In the face of this Sita not only exhibits her diplomacy but also plans ahead for the sustainable development of her kingdom. She receives hundred thousand gold coins as donation in order to "establish her authority in the kingdom" but uses that money for public welfare, that is, in improving roads, water and housing conditions of the poor people of her 
University of Bucharest Review $\approx$ Vol. XI/2021, no. 2 (new series)

Re-writing, Re-imagining the Past (IV)

kingdom. She feels that building a road would revitalize trade and make Mithila wealthy and self sufficient and building houses for the slum dweller would make them happy and less troublesome. Thus she gives primacy to "two potential projects that needed investment. One was the road that connected Mithila to Sankashya. The other was cheap, permanent and liveable housing for the slum dwellers" (109). Sita understands the importance of the regular availability of clean drinking water that the enemy could not poison, so she had a deep lake dug in the city thereby proving herself to be an able administrator and socialist. The pliant Sita of the master-narrative is deconstructed by Amish and a new age educated, empowered and capable woman who asserts her personal power emerges in the current narrative.

\section{Conclusion}

McDowell analyses John Keene's theory of "counter-narratives" and says that, counter-narratives assert "the power of some stories to push back, challenge, or yes, counter the harm done by other stories" (McDowell n. pg.) Amish Tripathi recasts the story of Sita in a manner so as to defamiliarize and provide resistance against dominant, hegemonic, and mainstream narratives and values propagated by the narrative of the ancient text of the Ramayana. Women empowerment is an important facet of the current Indian political scenario where politicians and social theorists advocate for the rights of women and their agency and equal participation in social, political and religious activities. "Women empowerment aims to provide women equal opportunities as well. It is the process of supporting women, to help them discover and provide them with the support to assert their personal power. The laws are enacted to empower women by granting them political power and by helping women achieve economic control and authority through education and social upliftment" (Dev 70). Yet master-narratives with their subtle socio-psychological soft power continue to dominate women and deny them agency. Therefore, contemporary writers like Amish Tripathi feel the urgency of counter-narrating canonical texts. Amish's counter-narration of The Ramayana illustrates empirically how writers in recasting stories counter-narratively contest meaning, redefine their identities and subject positions, and claim for more political power. In fact, we can agree with John Keene that every story, every master-narrative needs to be counternarrated with new perspectives, new voices, new versions so that these "stories help restore agency, depth, and dignity to figures formerly denied full 
representation" (McDowell n. pg.), such as Sita. In the present times when women empowerment and equality of the sexes is vehemently advocated Amish Tripathi's perspective in his novel Sita brings about a correspondence between the expectation of the contemporary writer and the reader. The expectation of the reader is influenced by time, space, politics and media. Taking this into consideration Amish has challenged the patriarchal hegemony of the original text. While keeping the characters and settings in the novel similar to that of the original text, he counter-narrates it and produces a different network of signifiers and meanings conducive to present times.

\section{Works Cited}

Raman, Sita Anantha. Women in India: A Social and Cultural History. Vol. 1, Praeger, 2009.

R., Basuki, and Setiawan D. "Reinterpreting Ramayana: The (Re)Production of the Meanings of Power in 'Ramayana', an East Javanese Shadow Puppet Performance Text." k@Ta, vol. 14, no. 1, 2012.

Bennet, Alex. "Storytelling: The Thread of Humanity." Research Gate, Apr. 2015. https://www.researchgate.net/publication/275522646_Storytelling_The_Thread_o f_Humanity.

Dev, Shampa. Gender Justice in India: A Feminist Jurisprudential Perspective. Tattva-Journal of Philosophy. Vol. 10, No. 1, 2018: 69-88.

Devakaruni, Chitra. The Forest of Enchantments. HarperCollins Publishers, 2019.

Dutt, Manmatha Nath. Ed. The Ramayana. Deva Press, 1891.

Hyvärinen, Matti. Narrative Contestations Review Essay. Forum: Qualitative Social Research.Volume 8. 3, Art. 34, June 2007.

https://www.qualitative-research.net/index.php/fqs/article/view/299/658

Lueg, Klarissa, and Marianne Wolff Lundholt. "What Counter-Narratives Are: Dimensions and Levels of a Theory of Middle Range." Routledge Handbook of Counter-Narratives, Routledge, London, 2020.

McDowell, Eric. "Counter-narratives: The Power of Narrative." Michigan Quarterly Review, 7 Aug. 2015.

https://sites.lsa.umich.edu/mqr/2015/08/counternarratives-the-power-ofnarrative/.

Morris, Pam. Literature and Feminism: An Introduction. Wiley-Blackwell, 1993.

Oppermann, Serpil. The Interplay between Historicism and Textuality: Postmodern 
University of Bucharest Review $\propto$ Vol. XI/2021, no. 2 (new series)

Re-writing, Re-imagining the Past (IV)

Histories. Hacettepe Universitesi Edebiyat Fakültesi Dergisi Cilt 16/ Say1 I/ss. 2016: 13-27.

Patwari, Hriday N. Women as depicted in the Manusmriti. The Modern Rationalist. 1 December 2020,

http://modernrationalist.com/women-as-depicted-in-the-manusmriti/

Svane, Marita. "Counter-narratives and counter-stories: The dynamics of dialectical dialogical storytelling." Routledge Handbook of Counter- Narratives. Klarissa Lueg and Marianne Wolff Lundholt (eds.). Routledge, 2021.

Tripathi, Amish. Sita: Warrior of Mithila. Westland Publications, 2017.

White, Hayden. "The Historical Text as Literary Artefact" in The Writing of History: Literary Form and Historical Understanding. Eds. Robert H. Canary and Henry Kozicki. Wisconsin Press, 1978: 41-62.

Format: (B5) $17,7 \times 25 \mathrm{~cm}$

Font: Times New Roman (Size 11/9)

Tiparul s-a executat sub cda. 4761 / 2020,

la Tipografia Universității din Bucureşti 